\section{Seismic investigation to go ahead}

FRENCH geoscientists have won approval for a large-scale seismological investigation of the geological substructure of France The programme, to be known as ECORS (Etude de la croûte terrestre en France par méthode sismique), is to extend over five years. It will involve the study of five cross-

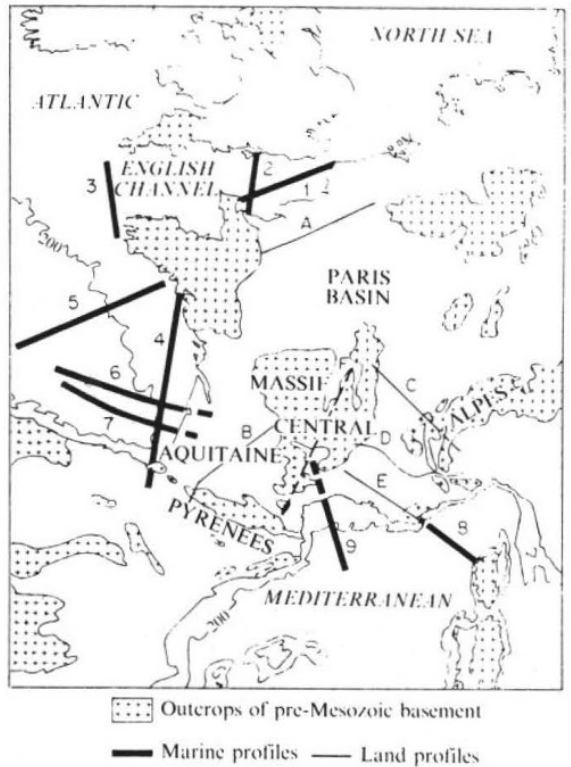

section profiles on land, each 200-300 km long and up to $40 \mathrm{~km}$ deep, and nine profiles at sea. A preliminary estimate puts the

The French survey provides for symbiotic collaboration between academic and industrial geophysics. It will be administered and financed by three organizations from government and industry - the Institut Français de Petrole (IFP), the Société National Elf Aquitaine and the de Physique du Globe in Paris. techniques. Atlantic Ocean. be organized. cost at about FF170 million ( $£ 16.5$ million).

Institut National d'Astronomie et de Geophysique of the Centre National de la Recherche Scientifique. The supervisory committee is under the chairmanship of $C$. Salle of IFP and the scientific committee under that of Claude Allègre of the Institut

The use of seismic refraction profiling (in which explosions are used to initiate seismic wave propagation in the crust) is well established, but more sensitive and deeper crustal profiling has been made possible in recent years by seismic reflection profiling. This technique, developed principally in the prospecting industry, uses acoustic waves as in an echo-sounder. The waves initiated at the surface are reflected from regions of contrasted density (or, more precisely, acoustic impedance) and are subsequently picked up by "geophones" placed along the surface of the profile. Professor Allègre stresses that both reflection and refraction techniques can be developed further, and that a significant part of the ECORS effort will be spent on the development of theoretical techniques of inversion and seismic imaging to make the fullest use of the experimental

Work has already begun on the first profile, to be investigated this summer (profile A in the map shown). The sedimentary basin around Paris overlies geological structures dating back to the Carboniferous and Permian eras (between 225 and 345 million years ago) that preceded the opening of the

The subsequent profiles to be "shot" on land and sea are shown in the figure. Cooperation with neighbouring countries is to

Philip Campbell

\section{Human rights}

\section{Harassment in Estonia}

AT least fifteen human rights activists in Estonia campaigning for the release of Mark Niklus, a biologist serving a 15-year sentence in a strict labour camp near Perm, were last week subjected to police search and interrogations. Several scholars were involved and one of them, the architect Lahle Parek, has since been arrested.

Mark Niklus became a keen supporter of the Helsinki Watch movement in the 1970 s. He monitored and protested against breaches of human rights in the Estonian SSR, demanding in particular that the Estonian people be informed of the full text of the Moscow-Ribbentrop pact of August 1939, including the secret protocols by which the Baltic States were assigned to the Soviet Union. He was tried in 1979.

This is not Mr Niklus's first term of imprisonment - he served a 6-year sentence from 1958 to 1966 , for, according to his mother, taking advantage of an interna- tional ornithological conference in Tartu to convey to foreign colleagues snapshots "showing Soviet life as it really is". This time, however, his health has deteriorated considerably and, according to his supporters, an early release and permission to emigrate is probably the only way to save his life.

The harassment of his supporters last week suggests that the Soviet authorities will not look kindly on pleas for clemency. A few weeks ago, campaigners for Anatolii Shcharanskii were warned that reduction of sentence can be earned only by the prisoner's "repentance"'. And the heavy sentence imposed last week on Valerii Senderov, the Moscow activist who, among other things, monitored discrimination against Jewish applicants for university entrance - suggests that the current mood of the security authorities is one of draconian severity.

\section{Caspian gulf Whose finger in the dyke?}

A PLAN to stem the ecological damage caused by massive water loss from the Caspian Sea now seems to have backfired disastrously. The Kara-Bogaz dam, which separates the Kara-Bogaz-Gol gulf from the main part of the Caspian, was hailed last year as a major feat of environmental engineering. But by last autumn ecologists in the area were warning that unless steps were taken to prevent the Kara-Bogaz-Gol gulf from drying up, there would be largescale ecological damage (Nature 299, 384; 1982). Now, according to the Soviet newspaper Pravda, the problem has been officially recognized and the State Committee for Science and Technology has agreed that drastic remedial action is necessary.

In fact, the original purpose of the dam was to let the gulf dry up. The Caspian has suffered a net annual water deficit of 15 $\mathrm{km}^{3}$, of which $5 \mathrm{~km}^{3}$ was lost by evaporation from the Kara-Bogaz-Gol, which at $160 \mathrm{~km}$ long and $140 \mathrm{~km}$ broad but only 2 to $3 \mathrm{~m}$ deep formed a huge natural evaporation pan.

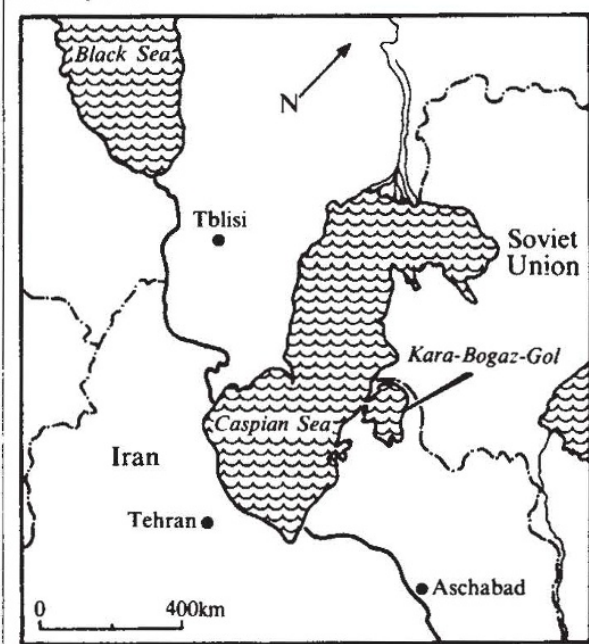

Since the dam was completed in March 1980 , the area of the gulf has shrunk from $18,000 \mathrm{~km}^{2}$ to $6,000 \mathrm{~km}^{2}$ and the depth is down to $50 \mathrm{~cm}$. This has been disastrous for the local chemical industry, run by the Carabogazsulfat trust, which is based on sulphate-rich subterranean brines. Moreover ecologists now feel that if the gulf dries out completely, the resulting salt deposits could be blown inland, ruining fertile lands and fish farms for hundreds of kilometres.

The obvious solution would be a sluice in the dam to allow in just sufficient water to prevent contamination. Such a sluice was eliminated from the final design apparently because of disagreements over cost. Now, however, says Pravda, the State Committee for Science and Technology has decided that a sluice must be constructed at once.

Vera Rich 